\title{
ANALISIS KERUSAKAN BATANG ROTOR PADA MOTOR INDUKSI TIGA FASA MENGGUNAKAN METODE MOTOR CURRENT SIGNATURE ANALYSIS
}

\author{
Niko Riza Firdhana ${ }^{*}$, Tejo Sukmadi, dan Karnoto \\ Departemen Teknik Elektro, Universitas Diponegoro Semarang \\ Jl. Prof. Sudharto, SH, Kampus UNDIP Tembalang, Semarang 50275, Indonesia \\ ${ }^{*}$ E-mail :firdhanariza@gmail.com
}

\begin{abstract}
Abstrak
Motor induksi digunakan di berbagai bidang karena harganya murah, handal, dan memiliki efisiensi yang tinggi. Salah satu penggunaan motor induksi adalah pada unit pembangkit listrik. Motor induksi dapat mengalami kegagalan karena proses penuaan dan bebagai faktor lain yang berkaitan dengan pola operasi. Salah satu kegagalan motor induksi disebabkan oleh rusaknya batang rotor. Untuk mengurangi kegagalan motor induksi diperlukan adanya pemantauan untuk melihat kondisi dan unjuk kerja motor induksi. Salah satu metode yang digunakan dalam pemantauan kondisi adalah Motor Current Signature Analysis (MCSA). Metode ini melakukan pendekatan sinyal arus stator untuk mendeteksi side band frequency di sekitar terminal sumber. Penelitian ini merancang desain GUI yang berisi analisis kondisi batang rotor menggunakan metode MCSA, persentase keseimbangan arus dan tegangan untuk menganalisis kondisi motor induksi yang ada di PT. PJB UBJOM PLTU Rembang yaitu Medium Speed Mill 20 A dan Medium Speed Mill 20D. Kondisi batang rotor pada kedua motor semakin memburuk seiring bertambahnya beban. Meskipun semakin memburuk, tetapi kondisi keseimbangan arus dan tegagan kedua motor normal karena berada di bawah $5 \%$ dan $10 \%$.
\end{abstract}

Kata kunci: motor induksi, motor current signature analysis, keseimbangan tegangan

\begin{abstract}
Induction motors are used in many fields because they are cheap, reliable, and have high efficiency. The induction motor can fail due to the aging process and other factors related to the pattern of operation. One induction motor failure is caused by the broken rotor bar. To reduce the induction motor failure it is necessary to have condition monitoring to see the performance of the induction motor. One of the methods used in condition monitoring is Motor Current Signature Analysis (MCSA). This method approximates the stator current signal to detect the side band frequency around the source terminal. This research designs GUI design that contains rotor bar condition analysis using MCSA method, current and voltage balance percentage to analyze induction motor condition in PT. PJB UBJOM PLTU Rembang,i.e Medium Speed Mill 20 A and Medium Speed Mill 20D. Rotor bar condition of both motor decreases with increasing load. However, the current and voltage balance condition of both motors is normal because the balance condition is below $5 \%$ and $10 \%$.
\end{abstract}

Key words: induction motor, motor current signature analysis, voltage imbalance

\section{Pendahuluan}

Pada saat ini, motor induksi digunakan di berbagai bidang karena harganya murah, handal, dan memiliki efisiensi yang tinggi. Dalam unit pembangkitan listrik, motor induksi merupakan peralatan yang penting untuk menunjang sistem utama pada unit pembangkit tersebut. Motor induksi dapat mengalami kegagalan karena proses penuaan alami dan berbagai faktor lain yang berkaitan dengan pola operasi. Apabila kegagalan pada motor induksi tidak dideteksi pada saat permulaan, maka motor induksi dapat rusak dan berujung pada shutdown dari proses produksi sehingga dapat mengakibatkan kerugian pada sebuah pembangkit listrik [1]. Kegagalan motor induksi pada salah satu pembangkit listrik di Indonesia, yaitu PLTU Rembang secara umum disebabkan oleh dua faktor, yaitu kegagalan yang berkaitan 
dengan stator $(50 \%)$ dan rotor $(50 \%)[2]-[4]$. Kerusakan batang rotor berpengaruh pada arus stator yang dihasilkan [5]. Melalui pendekatan sinyal arus stator untuk mendeteksi side band frequency di sekitar terminal sumber, akan didapatkan karakteristik spektrum yang merepresentasikan tingkat kerusakan batang rotor pada motor induksi secara real time $[5,6]$. Gangguan pada motor induksi dapat dideteksi pada saat permulaan dengan cara menganalisis gelombang arusnya yang disebut MCSA (Motor Current Signature Analysis) [7]. Gelombang arus tersebut didiagnosis dengan menggunakan teknik FFT (Fast Fourier Transform) dengan mengubah gelombang arus dari domain waktu menjadi domain frekuensi (spektrum). MCSA dilakukan secara online dengan memonitoring arus pada salah satu fasa dari suplai motor (single stator) tanpa mengganggu proses produksi pada motor dalam kondisi berbeban. Metode tersebut dapat digunakan sebagai alat pada bidang predictive maintenance di unit pembangkit listrik [7-10].

Penelitian ini membahas pembuatan condition monitoring pada software MATLAB - based Graphical User Interface (GUI) untuk mendeteksi tingkat kerusakan batang rotor dari motor induksi tiga fasa di PT PLN UBJOM PLTU Rembang dengan beban pada motor yang bervariasi. Untuk dapat mengetahui tingkat kerusakan batang rotor, maka digunakan standar EASA (Electrical Apparatus Service Association) Selain itu, pada penelitian ini juga akan dibahas mengenai perhitungan persentase keseimbangan arus dan tegangan berdasarkan standar NEMA MG-1 tahun 2009. Analisis kerusakan barang rotor sebelumnya telah dilakukan tetapi menggunakan metode Resampling Based Order Tracking Analysis[11]. Selain itu, metode MCSA pernah digunakan pada penelitian sebelumnya, tetapi metode tersebut digunakan untuk mendeteksi kerusakan pada bearing dan eccentricity[1,12]. Pembuatan simulasi pada Matlab sebelumya juga pernah dibuat [13], tetapi hanya untuk satu motor saja dan tidak dijelaskan perhitungan keseimbangan arus dan tegangan. Selain itu, pada penelitian tersebut analisis kerusakan batang tidak didasarkan pada standar EASA [14].

Tujuan dari pembuatan penelitian ini adalah melakukan simulasi perhitungan ketidakseimbangan tegangan dengan 7 tipe tegangan tak seimbang. Mengetahui kondisi batang rotor pada motor Medium Speed Mill 20 D. Mengetahui kondisi batang rotor pada motor Medium Speed Mill 20 A. Melakukan perhitungan persentase ketidakseimbangan arus dan tegangan pada kedua motor berdasarkan standar NEMA MG-1.

Cakupan permasalahan dalam penelitian ini adalah sebagai berikut :

1. Software yang digunakan adalah MATLAB based Graphical User Interface (GUI).
2. Jenis motor yang dianalisis adalah motor induksi tiga fasa.

3. Motor yang dianalisis adalah motor Medium Speed Mill 20 D dan Medium Speed Mill 20 A

4. Pengambilan data dilakukan di PT PLN UBJOM PLTU Rembang.

5. Metode yang digunakan untuk mengetahui status kondisi motor induksi tiga fasa adalah Motor Current Signature Analysis.

6. Bagian dari motor induksi tiga fasa yang diamati dengan metode MCSA adalah batang rotor.

7. Standar yang digunakan untuk menentukan keseimbangan arus pada motor induksi tiga fasa adalah NEMA MG-1 tahun 2009.

8. Parameter yang digunakan untuk mengetahui status kondisi motor induksi tiga fasa adalah slip frequency, line frequency, broken rotor bar frequency, dan $\Delta \mathrm{dB}$ (selisih antara line frequency amplitude dengan broken rotor bar frequency amplitude) serta persentase keseimbangan arus dan tegangan.

9. Standar yang digunakan untuk mengetahui status batang rotor dari motor induksi tiga fasa adalah EASA (Electrical Apparatus Service Association).

10. proses perubahan gelombang arus berdomain waktu ke domain frekuensi menggunakan teknik FFT (Fast Fourier Transform) tidak dibahas.

\section{Metode}

\subsection{Langkah Penelitian}

Diagram alir penelitian yang digunakan dalam penelitian ini ditunjukkan pada Gambar 1. Pada tahap awal dilakukan pengambilan data pada motor Medium Speed Mill 20 D dan Medium Speed Mill 20 A dengan beban yang bervariasi. Kemudian mendesain GUI pada software Matlab. Desain GUI dimaksudkan untuk melihat dan menganalisis kondisi motor berupa kondisi batang rotor, kondisi keseimbangan arus dan keseimbangan tegangan. Setelah itu memasukkan rumus ke dalam menu editor pada Matlab sehingga GUI dapat menampilkan hasil perhitungan keseimbangan arus dan tegangan serta dapat menampilkan spektrum arus pada motor. Kemudian uji coba pada GUI dilakukan untuk melihat apakah aplikasi berjalan dengan baik atau tidak. Apabila aplikasi tidak berjalan dengan baik, maka perlu dilakukan analisis error pada coding. Berdasarkan hasil perhitungan keseimbangan arus dan tegangan serta spektrum arus dari motor induksi, dilakukan analisis apakah motor dalam kondisi yang baik atau tidak. 


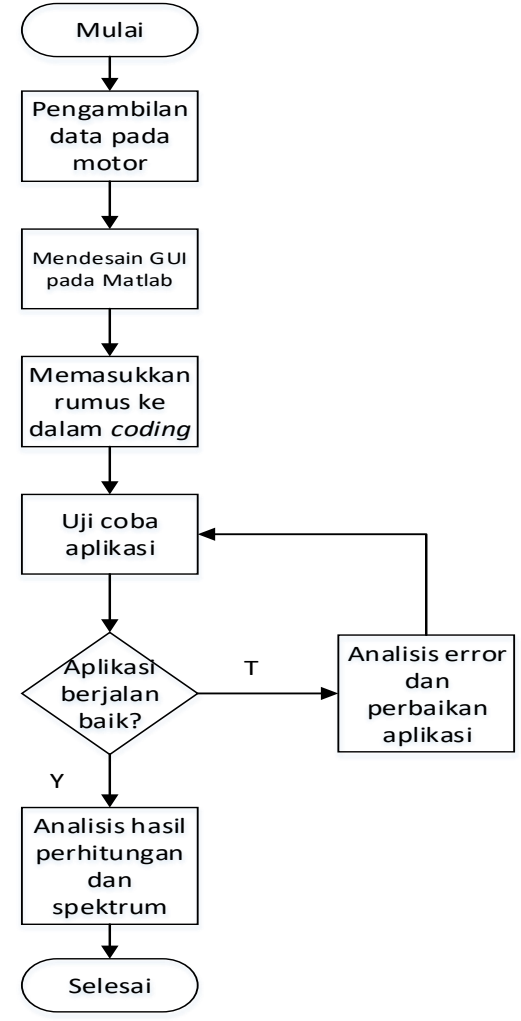

Gambar 1. Diagram Alir Penelitian

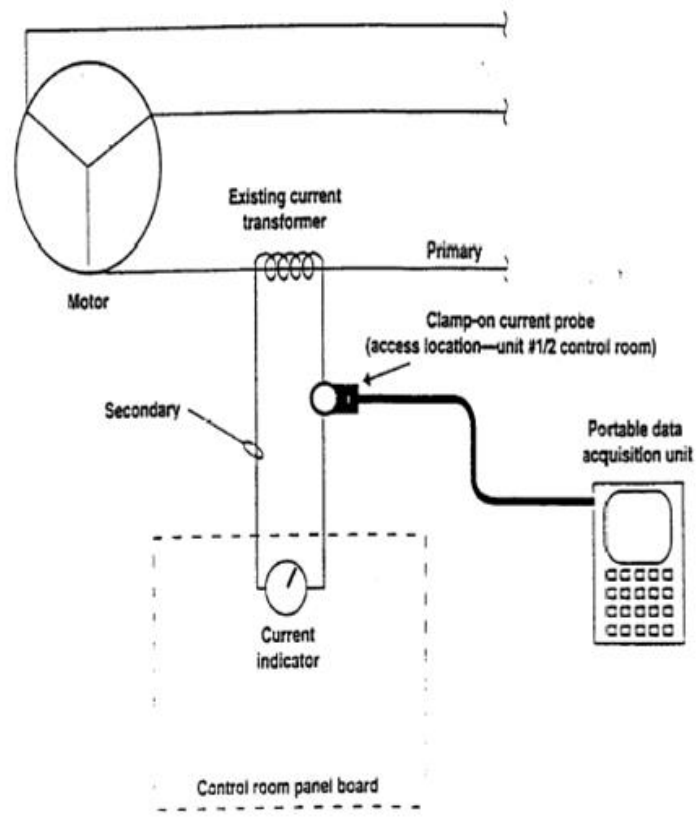

Gambar 2. Sistem instrumentasi dasar MCSA

\subsection{Motor Current Signature Analysis (MCSA)}

Gambar 2 menunjukkan skema instrumentasi dasar MCSA. MCSA adalah suatu metode condition monitoring pada motor induksi tiga fasa dengan cara menganalisis arus yang melewati winding stator. Arus pada stator akan dikonversikan ke dalam bentuk gelombang frekuensi terhadap waktu dengan clamp on ammeter. Arus motor difilter untuk menghilangkan harmonisa dari line frekuensi dan ditransformasikan ke domain frekuensi melalui FFT [15].

Masalah batang rotor akan ditandai dengan munculnya sideband di sekitar line frequency, seperti ditunjukkan pada Gambar 3 [16,17]. Indikator utama dari masalah rotor adalah perbedaan tinggi spectrum yang diukur dalam decibel, antara spike dari line frekuensi dan spike dari frekuensi pole pass dari signature arus motor. Semakin kecil perbedaan antara keduanya, mengindikasikan semakin parah kerusakan dari batang rotor.

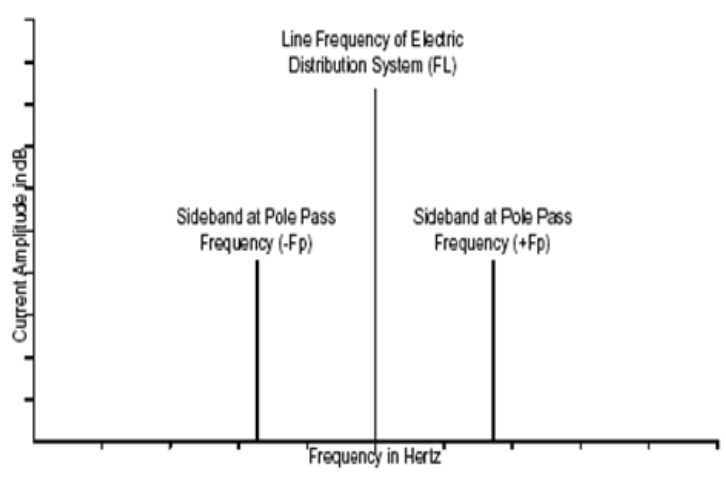

Gambar 3. Motor currrent signature [16]

\subsection{Objek Penelitian}

Tiap unit PLTU Rembang memiliki satu buah boiler dengan 5 mill pulveriser yang mensuplai bahan bakar ke ruang bakar. Mill pulveriser adalah alat yang digunaka untuk menghancurkan / menggiling batubara menjadi butiran halus, kemudian butiran ini dihembuskan dari bagian bawah mill pulveriser hingga menuju ruang bakar pada boiler. Mill pulveriser yag digunakan di PLTU Rembang adalah jernis Medium Speed Mill, seperti ditunjukkan pada Gambar 4. Tabel 1 menjelaskan spesifikasi motor Medium Speed Mill 20 A dan Medium Speed Mill 20 D.

Tabel 1. Spesifikasi motor Medium Speed Mill 20A dan Medium Speed Mill 20 D

\begin{tabular}{ccccccc}
\hline $\begin{array}{c}\text { Volts } \\
(\mathbf{V})\end{array}$ & $\begin{array}{c}\text { Power } \\
(\mathrm{Hp})\end{array}$ & $\begin{array}{c}\text { Amps } \\
(\mathbf{A})\end{array}$ & $\begin{array}{c}\text { Freq } \\
(\mathrm{Hz})\end{array}$ & $\begin{array}{c}\text { Rated } \\
\text { RPM }\end{array}$ & Pf & Connection \\
\hline 6300 & 697 & 51.7 & 50 & 979 & 0,83 & $\mathrm{Y}$ \\
\hline
\end{tabular}




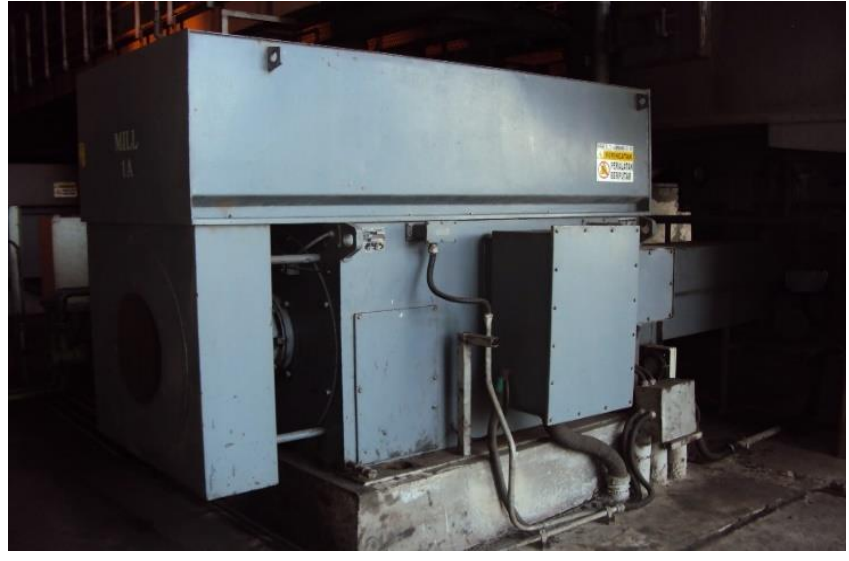

Gambar 4. Motor Medium Speed Mill

\section{Hasil dan Analisis}

\subsection{Kondisi Motor Medium Speed Mill 20 D}

\subsubsection{Kondisi pada Beban $17 \%$}

Hasi pengukuran pada motor Medium Speed Mill 20 D pada beban $17 \%$ adalah kecepatan putar rotor sebesar 996,3 RPM. Slip $=\frac{1000-996,3}{1000}$

$$
=0,0037
$$

$\mathrm{F}_{\mathrm{b}}=(50-2.0,0037.50)$

$=49,66 \mathrm{~Hz}$

Ketika motor berbeban $17 \%$, nilai dua kali slip yang diprediksi adalah 0,0074. Hal ini menunjukkan bahwa frekuensi kerusakan batang rotor terdapat pada $\pm 49,66 \mathrm{~Hz}$. Berdasarkan Gambar 5, frekuensi suplai berada pada $50 \mathrm{~Hz}$ dengan amplitudo $80 \mathrm{~dB}$, sedangkan frekuensi batang rotor yang rusak $(\mathrm{Fb})$ terdapat pada $49,6 \mathrm{~Hz}$ dengan amplitudo 12,45 dB. Nilai FP Amplitude diperoleh dari pengurangan antara amplitudo line frequency dengan amplitudo $\mathrm{Fb}$ dengan hasilnya adalah 67,55 dB.

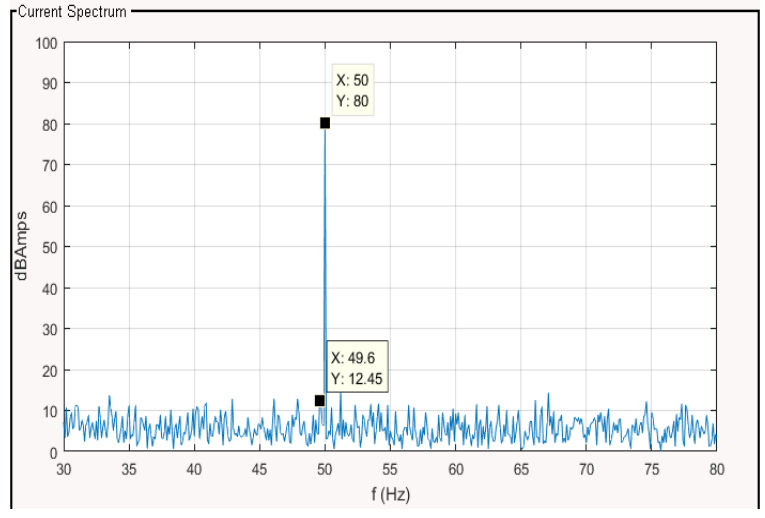

Gambar 5. Kondisi batang rotor motor Medium Speed Mill 20 D pada beban $17 \%$
Berdasarkan standar EASA, kondisi batang rotor pada beban $17 \%$ adalah "Good Motor" karena nilai FP Amplitude tersebut berada di atas $50 \mathrm{~dB}$. Hasil perhitungan frekuensi kerusakan batang rotor yang diprediksi dengan simulasi berbeda sebesar 0,06 Hz. Hal ini dikarenakan pada simulasi nilai frekuensi hanya menggunakan satu angka di belakang koma.

\subsubsection{Kondisi pada Beban $79 \%$}

Hasil pengukuran pada motor Medium peed Mill 20 D pda beban $79 \%$ adalah kecepatan putar rotor sebesar 984,6 RPM

$$
\begin{aligned}
\text { Slip } & =\frac{1000-984,6}{1000} \\
& =0,0154 \\
\mathrm{Fb} & =(50-2.0,0154.50) \\
= & 48,46 \mathrm{~Hz}
\end{aligned}
$$

Ketika motor berbeban $79 \%$, nilai dua kali slip yang diprediksi adalah 0,0308. Hal ini menunjukkan bahwa frekuensi kerusakan batang rotor terdapat pada $\pm 48,46 \mathrm{~Hz}$. Berdasarkan Gambar 6, frekuensi suplai berada pada $50 \mathrm{~Hz}$ dengan amplitudo $80 \mathrm{~dB}$, sedangkan frekuensi batang rotor (Fb) terdapat pada $48,4 \mathrm{~Hz}$ dengan amplitudo 37,67 dB. Terdapat selisih sebesar $0,06 \mathrm{~Hz}$ antara frekuensi yang diprediksi dari perhitungan dengan simulasi. Hal ini karena nilai frekuensi pada simulasi hanya menggunakan satu angka dibelakang koma. Nilai FP Amplitude adalah 42,33 dB. Dengan demikian kondisi batang rotor pada beban $79 \%$ adalah "Monitoring". Pada kondisi ini, motor masih dapat bekerja dengan tetap memantau kondisinya.

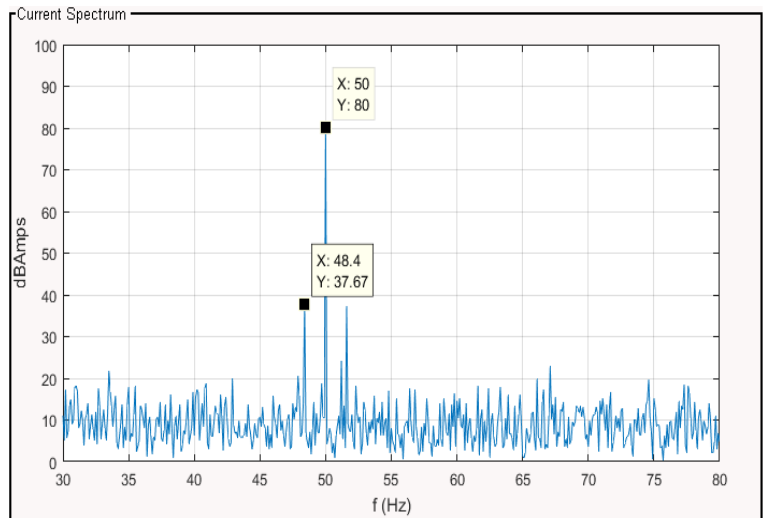

Gambar 6. Kondisi batang rotor motor Medium Speed Mill 20 D pada beban $79 \%$

\subsubsection{Kondisi pada Beban $67 \%$}

Pengukuran pada beban $67 \%$ tidak hanya berupa arusnya saja, tetapi pengukuran tambahan berupa rangkaian daya 
untuk melihat kondisi keseimbangan arus dan tegangan pada motor induksi tiga fasa. Perhitungan persentase keseimbangan arus dan tegangan menggunakan standar NEMA MG-1 sebagai acuan. Keseimbangan arus dan tegangan pada motor induksi tiga fasa diperoleh dari perhitungan berikut.

Voltage unbalance $=\frac{V_{L L}-V_{l l}}{V_{l l}} \times 100 \%$

Average $=(6491,44+6455,9+6473,83) / 3=6473,72$

Maximum deviation from average $=|6455,9-6473,72|=$ 17,82

Percent voltage imbalance $=\mathrm{x} 100 \%=0,28 \%$

Average $=(40,08+40,35+41) / 3=40,47$

Maximum deviation from average $=|41-40,41|=0,523$

Percent current imbalance $=\left[\frac{0,523}{40,47}\right] \times 100 \%=1,3 \%$

Berdasarkan Gambar 7, kondisi keseimbangan arus dibawah $10 \%$ dan tegangan pada motor dibawah $5 \%$. Berdasarkan standar NEMA MG-1, hal ini menunjukkan bahwa kondisi terebut normal. Nilai persentase keseimbangan tegangan adalah 0,28\% meyebabkan persentase keseimbangan arus menjadi $1,3 \%$. Selain itu untuk kondisi batang rotor, frekuensi batang rotor terdapat pada $48,6 \mathrm{~Hz}$ dengan amplitudo sebesar 28,81 dB sehingga diperoleh nilai FP Amplitude sebesar 51,19 dB. Berdasarkan standar EASA, kondisi batang rotor adalah normal karena nilainya lebih dari $50 \mathrm{~dB}$.

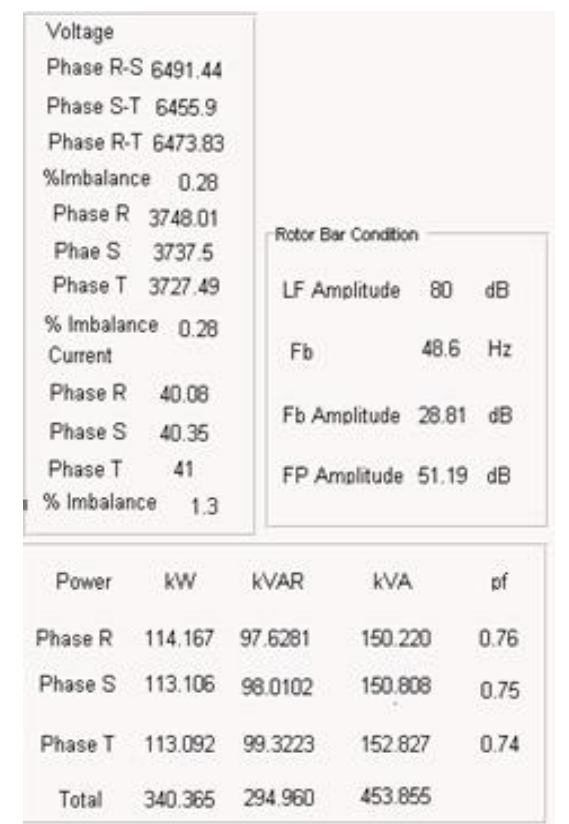

Gambar 7. Kondisi batang rotor dan Circuit Medium Speed Mill 20 D beban 67\%

\subsubsection{Kondisi pada Beban $73 \%$}

Pengukuran pada beban $73 \%$ juga dilakukan sama seperti pada beban $67 \%$ dimana ada pengukuran tambahan berupa power circuit untuk dapat mengetahui kondisi keseimbangan arus dan tegangan pada motor. Perhitungan keseimbangan arus dan tegangan pada motor sebagai perikut:

Percent voltaget imbalance $=\frac{V_{L L}-V_{l l}}{V_{l l}} \times 100 \%$

Average $=(6641,34+6637,59+6631,35) / 3=6636,76$

Maximum deviation from average $=|6631,35-6636,76|$

$=5,4$

Percent voltage imbalance $=\frac{5,4}{6636,76} \times 100 \%=0,08 \%$

Average $=(43,43+43,02+42,77) / 3=43,07$

Maximum deviation from average $=|43,07-42,77|=0,36$

Percent voltage imbalance $=\left[\frac{0,36}{43,07}\right] \times 100 \%=0,83 \%$

Berdasarkan Gambar 8, kondisi keseimbangan arus dan tegangan berdasarkan NEMA MG-1 pada beban $73 \%$ adalah normal karena keseimbangan arus kurang dari $10 \%$ dan keseimbangan tegangan kurang dari 5\%. Dari data 4 dapat diketahui ketidakseimbangan tegangan sebesar $0,28 \%$ menyebabkan ketidakseimbangan arus sebesar 0,83\%. Sedangkan kondisi batang rotor, frekuensi batang rotor terdapat pada 48,63 Hz dengan amplitudo sebesar 31,28 dB, sehingga nilai FP Amplitude yang diperoleh adalah 48,72 dB. Berdasarkan standar EASA, kondisi batang rotor adalah "Marginal Condition". Dalam kondisi ini, motor masih dapat beroprasi.

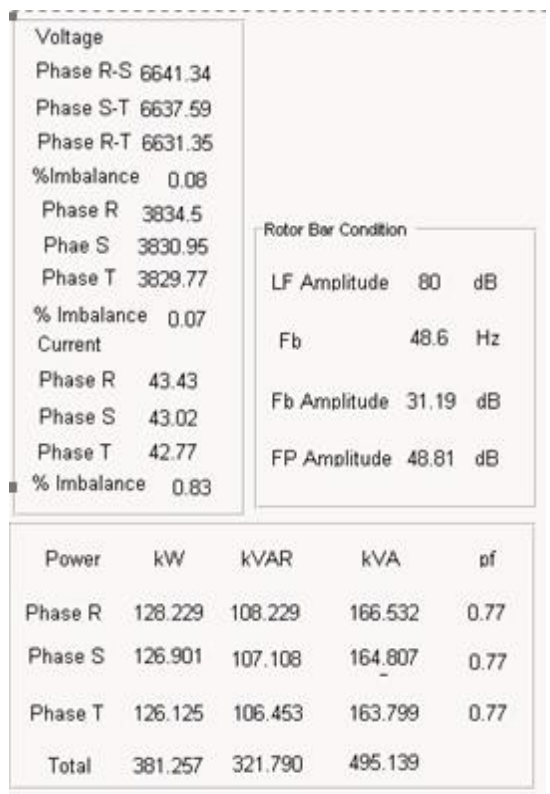

Gambar 8. Kondisi Batang Rotor dan Circuit Motor Medium Speed Mill 20 D beban 73\% 


\subsubsection{Rekapitulasi Data Medium Speed Mill 20 D}

Dari Tabel 2 dapat dibuat grafik hubungan beban dengan FP Amplitude seperti ditunjukkan pada Gambar 9. Dari Tabel 1 dan Gambar 9, dapat dilihat bahwa beban pada motor berpengaruh terhadap Fb dan FP Amplitude. Semakin besar beban yang diberikan kepada motor, maka nilai FP Amplitude semakin kecil. Sedangkan untuk Fb, semakin besar beban pada motor maka Fb akan semakin menjauh dari frekuensi suplai. Dengan demikian, dapat diketahui bahwa metode Motor Current Signature Analysis hanya cocok digunakan pada motor dengan beban di atas $50 \%$. Hal ini ditunjukkan pada saat motor berbeban $17 \%$, nilai FP Amplitude mencapai 67,5 dB. Sedangkan ketika motor mulai berbeban 67\%, nilai FP Amplitude turun menjadi 51,19 dB dan semakin besar beban yang diberikan pada motor, nilainya semakin berkurang.

\section{Tabel 1. Rekapitulasi Data Medium Speed Mill 20 D}

\begin{tabular}{ccccc}
\hline Data & $\begin{array}{c}\text { Load } \\
(\mathbf{\%})\end{array}$ & $\begin{array}{c}\mathbf{F}_{\mathbf{b}} \\
(\mathbf{H z})\end{array}$ & $\begin{array}{c}\mathbf{F}_{\mathbf{b}} \text { Amplitude } \\
\mathbf{( H z )}\end{array}$ & $\begin{array}{c}\text { FP Amplitude } \\
(\mathbf{d B})\end{array}$ \\
\hline 1 & 17 & 49,6 & 12,5 & 67,5 \\
2 & 67 & 48,6 & 28,81 & 51,19 \\
3 & 73 & 48,6 & 31,19 & 48,81 \\
4 & 79 & 48,4 & 37,67 & 42,33 \\
\hline
\end{tabular}

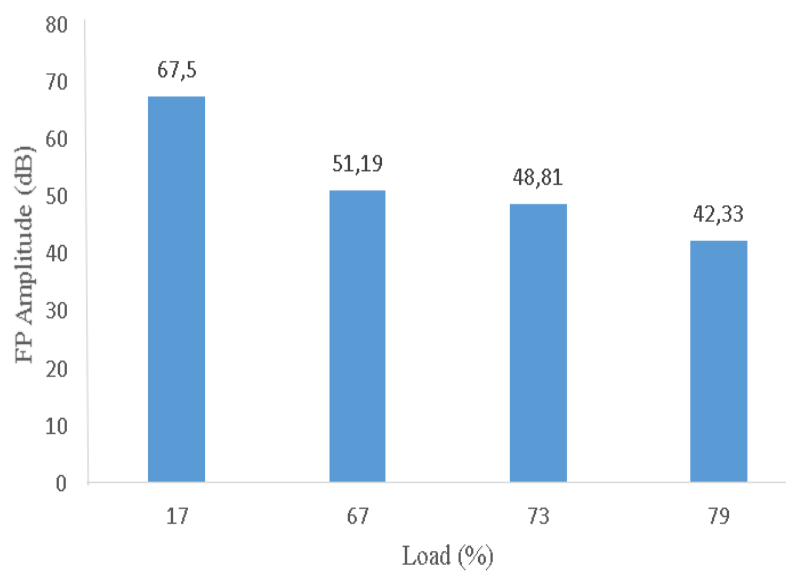

Gambar 9. Grafik hubungan beban dengan FP Amplitude pada Medium Speed Mill 20 D

\subsection{Kondisi Motor Medium Speed Mill 20 A \\ 3.2.1. Kondisi pada Beban $26 \%$}

Hasi pengukuran pada motor Medium Speed Mill 20 A pada beban $26 \%$ adalah kecepatan putar rotor sebesar 995,3 RPM. Slip $=\underline{1000-995,3}$

$$
\begin{array}{r}
1000 \\
=0,0047
\end{array}
$$

$$
\begin{aligned}
\mathrm{Fb} & =(50-2.0,0047.50) \\
& =49,53 \mathrm{~Hz}
\end{aligned}
$$

Ketika motor berbeban $26 \%$, nilai dua kali slip yang diprediksi adalah 0,0094. Dengan dimikian frekuensi kerusakan batang rotor terdapat pada $\pm 49,53 \mathrm{~Hz}$.

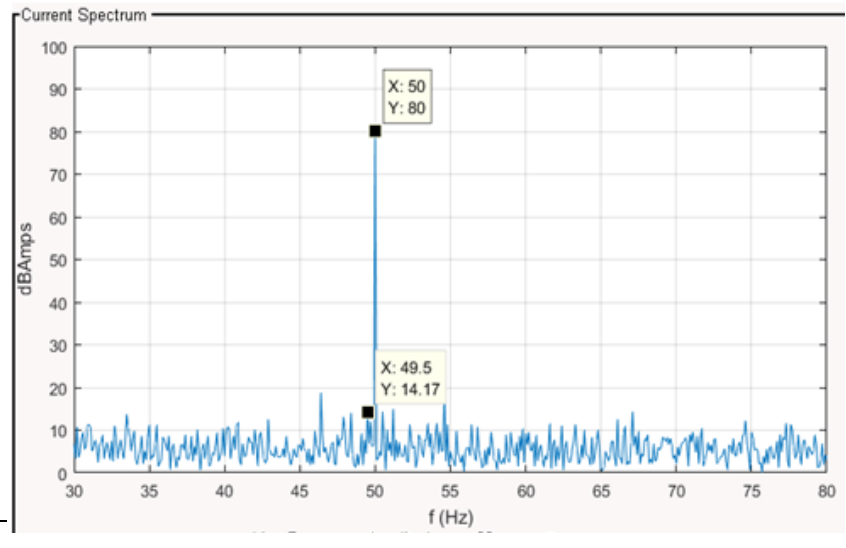

Gambar 10. Kondisi batang rotor Medium Speed Mill 20 A pada beban $26 \%$

Berdasarkan Gambar 10, frekuensi suplai berada pada $50 \mathrm{~Hz}$ dengan amplitudo $80 \mathrm{~dB}$, sedangkan frekuensi batang rotor yang rusak $(\mathrm{Fb})$ terdapat pada $49,5 \mathrm{~Hz}$ dengan amplitudo 14,17 dB. Nilai FP Amplitude diperoleh dari pengurangan antara amplitudo line frequency dengan amplitudo $\mathrm{Fb}$ dengan hasilnya adalah 65,83 dB. Berdasarkan standar EASA, kondisi batang rotor pada beban $77 \%$ adalah "Good" karena nilai FP Amplitude tersebut berada di atas $60 \mathrm{~dB}$. Pada kondisi ini, kondisi batang rotor pada motor induksi tiga fasa baik. Hasil perhitungan frekuensi kerusakan batang rotor yang diprediksi dengan simulasi berbeda sebesar 0,03 Hz. Hal ini dikarenakan pada simulasi, penunjukkan frekuensi batang rotor hanya menggunakan satu angka di belakang koma.

\subsubsection{Kondisi pada Beban $77 \%$}

Hasi pengukuran pada motor Medium Speed Mill 20 A pada beban $77 \%$ adalah kecepatan putar rotor sebesar 990 RPM dan besarnya arus pada fasa $\mathrm{R}$ adalah 40,7 A.

$$
\begin{aligned}
\text { Slip } & =\frac{1000-985,6}{1000} \\
& =0,0144
\end{aligned}
$$

$\mathrm{Fb}=(50-2.0,0144.50)$

$$
=48,56 \mathrm{~Hz}
$$

Ketika motor berbeban $77 \%$, nilai dua kali slip yang diprediksi adalah 0,0288. Dengan dimikian frekuensi kerusakan batang rotor terdapat pada $\pm 48,56 \mathrm{~Hz}$. 
Berdasarkan Gambar 11, frekuensi suplai berada pada $50 \mathrm{~Hz}$ dengan amplitudo $80 \mathrm{~dB}$, sedangkan frekuensi batang rotor yang rusak $(\mathrm{Fb})$ terdapat pada $49 \mathrm{~Hz}$ dengan amplitudo 31,7 dB. Nilai FP Amplitude diperoleh dari pengurangan antara amplitudo line frequency dengan amplitudo $\mathrm{Fb}$ dengan hasilnya adalah $48,4 \mathrm{~dB}$.

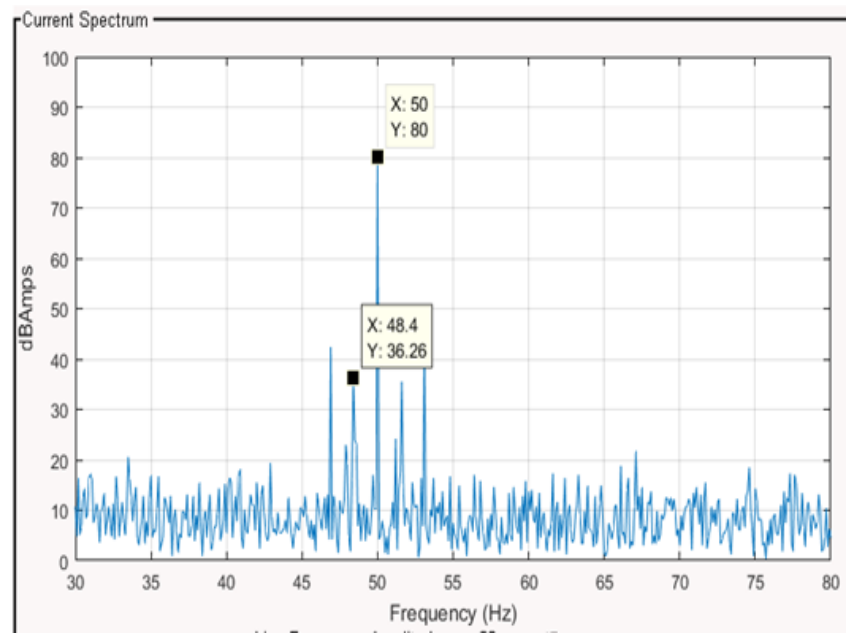

Gambar 11. Kondisi batang rotor Medium Speed Mill 20 A pada beban $77 \%$

Berdasarkan standar EASA, kondisi batang rotor pada beban 77\% adalah "Marginal Condition" karena nilai FP Amplitude tersebut berada di antara 45-50 dB. Pada kondisi ini, motor masih dapat dioperasikan.

\subsubsection{Kondisi pada Beban $68 \%$}

Pengukuran pada beban $68 \%$ dilakukan dengan pengukuran tambahan berupa power circuit untuk dapat mengetahui kondisi keseimbangan arus dan tegangan pada motor. Berikut merupakan perhitungan keseimbangan arus dan tegangan pada motor.

Percent voltaget imbalance $=\frac{V_{L L}-V_{l l}}{V_{l l}} \times 100 \%$

Average $=(6565,43+6463,4+6459,42) / 3=6451,1$ Maximum deviation from average $=|6459,42-6451,1|=$ 1,42

Percent voltage imbalance $=\frac{1,42}{6451,1} \times 100 \%=0,02 \%$

Average $=(40,78+41,83+41,86) / 3=41,49$

Maximum deviation from average $=|40,78-41,49|=0,71$

Percent current imbalance $\frac{0,71}{41,49} \times 100 \%=1,71 \%$

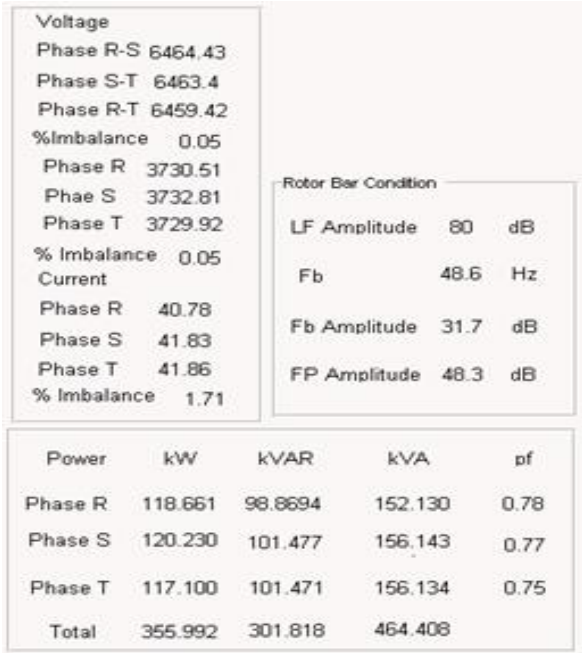

Gambar 12. Kondisi batang rotor dan Circuit Medium Speed Mill 20 A pada beban $68 \%$

Berdasarkan Gambar 12, kondisi keseimbangan arus dan tegangan berdasarkan NEMA MG-1 pada beban $68 \%$ adalah normal karena keseimbangan arus kurang dari $10 \%$ dan keseimbangan tegangan kurang dari 5\%. Dari data 3 dapat diketahui ketidakseimbangan tegangan pada perhitungan sebesar $0,02 \%$, sedangkan pada pengambilan data sebesar $0,05 \%$. Namun, ketidakseimbangan arus pada perhitungan dan pengambilan data sudah sama, yaitu $1,71 \%$. Untuk kondisi batang rotor, frekuensi batang rotor terdapat pada $48,6 \mathrm{~Hz}$ dengan amplitudo sebesar $31,7 \mathrm{~dB}$, sehingga nilai $\mathrm{FP}$ Amplitude yang diperoleh adalah 48,3 dB. Berdasarkan standar EASA, kondisi batang rotor adalah "Monitoring". Dalam kondisi ini, motor masih dapat beroprasi dengan tetap memonitoring dan trending data.

\subsubsection{Kondisi pada Beban $80 \%$}

Pengukuran pada beban $80 \%$ dilakukan dengan pengukuran tambahan berupa power circuit untuk dapat mengetahui kondisi keseimbangan arus dan tegangan pada motor. Berikut merupakan perhitungan keseimbangan arus dan tegangan pada motor.

Percent voltaget imbalance $=\frac{V_{L L}-V_{l l}}{V_{l l}} \times 100 \%$

Average $=(6459,31+6480,01+6461,83) / 3=6467,05$

Maximum deviation from average $=|6480,01-6467,05|$ $=12,96$

Percent voltage imbalance $=\frac{12,96}{6467,05} \times 100 \%=0,2 \%$

Average $=(49,32+48,64+48,33) / 3=48,76$

Maximum deviation from average $=|49,32-48,76|=0,56$

Percent current imbalance $=\left[\frac{0,56}{48,76}\right] \times 100 \%=1,15 \%$ 
Berdasarkan Gambar 13, kondisi keseimbangan arus dan tegangan berdasarkan NEMA MG-1 pada beban 79\% adalah normal karena keseimbangan arus kurang dari $10 \%$ dan keseimbangan tegangan kurang dari 5\%. Persentase keseimbangan tegangan adalah $0,2 \%$ mengakibatkan persentase keseimbangan arus menjadi $1,15 \%$.

Sedangkan kondisi batang rotor, frekuensi batang rotor terdapat pada 48,3 Hz dengan amplitudo sebesar 42,04 dB, sehingga nilai FP Amplitude yang diperoleh adalah 37,96 dB. Berdasarkan standar EASA, kondisi batang rotor adalah "Dangerous". Dalam kondisi ini, direkomendasikan motor harus shut down dan dilakukan inspeksi.

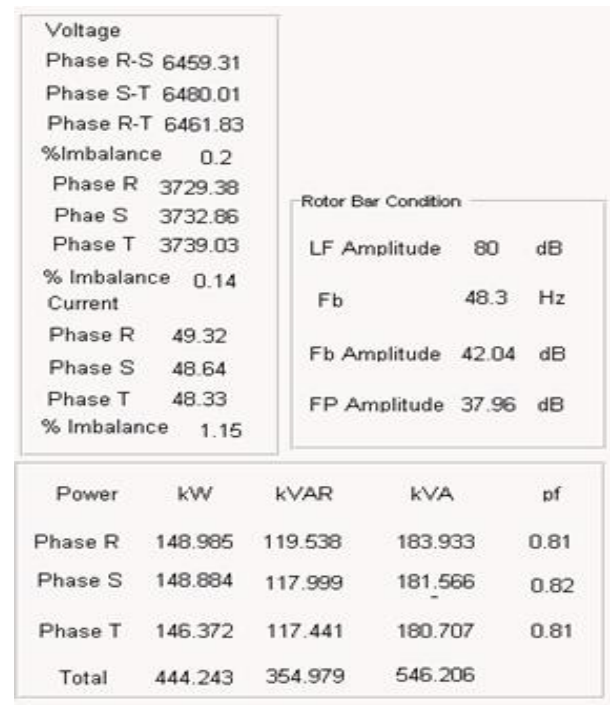

Gambar 13. Kondisi batang rotor dan Circuit MediumSpeed Mill 20 A pada beban $79 \%$

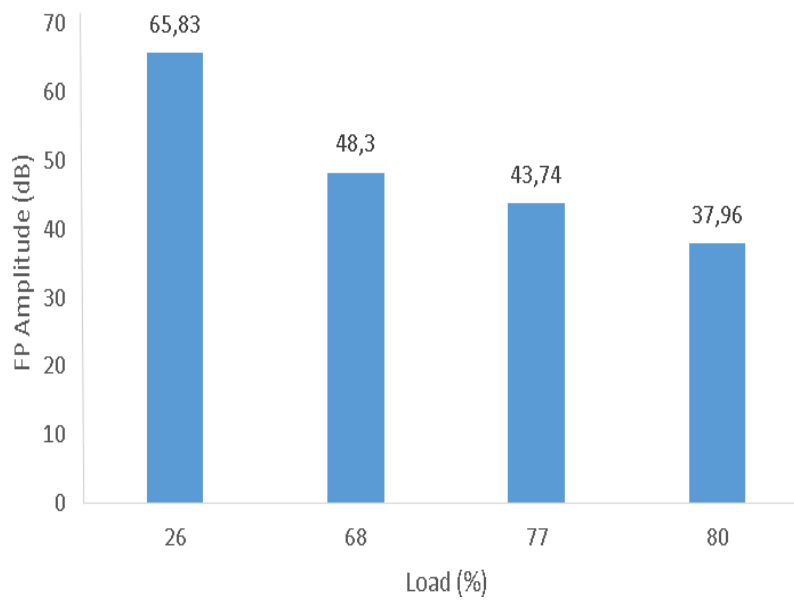

Gambar 14. Grafik hubungan beban dengan FP Amplitude pada Medium Speed Mill 20 A

\subsubsection{Rekapitulasi Data Medium Speed Mill 20 A}

Dari Tabel 3 dan Gambar 14 dapat diketahui bahwa semakin besar beban pada motor, maka nilai FP Amplitude semakin kecil. Hal ini ditunjukkan pada beban $26 \%$, nilai FP Amplitude adalah 65,83 dB dan seiring bertambahnya beban nilainya terus menurun sampai $37,96 \mathrm{~dB}$ pada beban $80 \%$.

Tabel 2. Rekapitulasi Data Medium Speed Mill 20 A

\begin{tabular}{ccccc}
\hline Data & $\begin{array}{c}\text { Load } \\
(\mathbf{\%})\end{array}$ & $\begin{array}{c}\mathbf{F}_{\mathrm{b}} \\
\mathbf{( H z )}\end{array}$ & $\mathbf{F}_{\mathrm{b}}$ Amplitude $(\mathbf{H z})$ & $\begin{array}{c}\text { FP Amplitude } \\
(\mathbf{d B})\end{array}$ \\
\hline 1 & 26 & 49,5 & 14,17 & 65,83 \\
2 & 68 & 48,6 & 31,7 & 48,3 \\
3 & 77 & 48,4 & 36,26 & 43,74 \\
4 & 80 & 48,3 & 42,04 & 37,96 \\
\hline
\end{tabular}

\section{Kesimpulan}

Berdasarkan analisis yang telah dilakukan pada penelitian ini, pada motor Medium Speed Mill 20 D, nilai FP Amplitude pada beban $17 \%$ adalah $67,5 \mathrm{~dB}$. Nilai FP Amplitude semakin menurun seiring dengan bertambahnya beban pada motor. Hal ini dapat dilihat pada beban $67 \%$ nilainya $51,19 \mathrm{~dB}$, pada beban $73 \%$ nilai FP Amplitude adalah $48,81 \mathrm{~dB}$, dan pada beban $79 \%$, nilainya mencapai 42,3 dB. Sama halnya dengan dengan motor Medium Speed Mill 20 D, nilai FP Amplitude pada motor Medium Speed Mill 20 A juga semakin menurun seiring bertambahnya beban. Pada beban 26\%, nilai FP Amplitude adalah 65,83 $\mathrm{dB}$, pada beban $68 \%$, nilainya $48,3 \mathrm{~dB}$, pada beban $77 \%$ nilainya $43,74 \mathrm{~dB}$, dan ketika beban $80 \%$ nilainya hanya $37,96 \mathrm{~dB}$. Kedua motor memiliki kondisi batang rotor yang baik pada beban di bawah $50 \%$, tetapi ketika beban di atas $70 \%$ kondisinya memburuk. Hal ini membuktikan bahwa metode Motor Current Signature Analysis hanya cocok digunakan ketika motor berbeban minimal $70 \%$. Motor Medium Speed Mill 20 A memiliki kondisi batang rotor yang lebih buruk dari motor Medium Speed Mill 20 D. Hal ini ditunjukkan pada nilai FP Amplitude pada beban 80\%, motor Mill A bernilai 37,96 dB, sedangkan motor Mill D bernilai 42,3 dB. Berdasarkan standar EASA, ketika nilai FP Amplitude bernilai 36-42 diprediksi terdapat dua batang rotor yang rusak / retak. Kondisi keseimbangan arus dan tegangan pada kedua motor adalah normal. Hal ini terlihat pada motor Mill D ketika berbeban 67\%, persentase ketidakseimbangan tegangannya adalah $0,28 \%$, pada beban $73 \%$ persentase ketidakseimbangan tegangannya adalah $0,08 \%$. Berdasarkan standar NEMA MG-1, kondisi tersebut normal karena persentase ketidakseimbanagnnya kurang dari 5\%. Motor Mill A juga memiliki kondisi keseimbangan arus dan tegangan yang normal. Pada beban $68 \%$, persentase ketidakseimbangan tegangannya adalah $0,05 \%$ dan pada beban $80 \%$ nilainya adalah $0,2 \%$. 


\section{Referensi}

[1]. I. G. P. Yudiastwan, "Deteksi Kerusakan Bearing dan Eccentricity pada Motor Induksi Tiga Fasa dengan Current Signature Analysis," tesis Universitas Indonesia, 2009.

[2]. Laporan Online and Offline Test Motor Listrik, PLTU Rembang, Rembang, Indonesia, 2015.

[3]. Laporan Online and Offline Test Motor Listrik, PLTU Rembang, Rembang, Indonesia, 2016.

[4]. Laporan Online and Offline Test Motor Listrik, PLTU Rembang, Rembang, Indonesia, 2017.

[5]. Broken Rotor Bar and Motor Malfunctions, Machine Library, hal.57.

[6] T. Wildi, Electrical Machines, Drive, and Power System, 5th ed. New Jersey,USA: Pearson Education, 2002.

[7] N. Mehala, R. Dahiya,"Motor Current Signature Analysis and its Applications in Motor Fault Diagnosis," International Journal of Systems Applications, Engineering \& Development, vol. 2, No.1, hal. 29-35 2007.

[8]. The National Electrical Manufacturers Association, MG 12009.

[9]. D. Miljkovic, "Brief review of motor current signature analysis." HDKBR Info magazin, vol. 5 No.1, hal. 14-26, 2015

[10]. W. T. Thomson, R. J. Gilmore,’Motor Current Signature Analysis to Detect Faults in Induction Motor DrivesFundamentals, Data Interpretation, and Industrial Cage
Histories", Proceeding of the Thirty-Second Turbomachinery Symposium, Houston, Texas, Sept.2003, hal.145-156.

[11] T. Dogruer, M. Akar, "Broken Rotor Bar Fault Diagnosis in Induction Motor using Resampling Based Order Tracking Analysis Method," JNRS, no.12, hal. 111-125, Sep. 2016.

[12]. A.M. Da Silva,"Induction Motor Fault Diagnostic and Monitoring Method", tesis, Electrical and Computer Engineering, Marquette University, Milwaukee, Wisconsin, 2006.

[13] S. R. Chandra, G.S. Ayyappan, K. Srinivas, and D. Ganesh, "Simulation and Testing of Induction Motor Faults in MATLAB for Online Condition Monitoring," IUP Journal of Electrical \& Electronics Engineering, vol. 9, no.12, hal.7-18, 2016.

[14]. Squirrel Cage Rotor Testing, EASA, 2003.

[15]. A. Naid, F. Gu, Y. Shao, S. Arbi, and A. Ball, "Bispectrum Analysis of Motor Current Signal for Fault Diagnosis of Reciprocating Comperssors," Key Engineering Materials, hal. 505-511, 2009.

[16]. A.V. Tostky, A.A. Zelensky, and V.F. Kravchenko, Bispectral Methods of Signal Processing. Germany: Deutsche Nationalbibliothek, 2015, hal.5.

[17]. L. Youb,'Effect of Unbalanced Voltage on Steady State of the Induction Motors," International Journal of Electrical Energy, vol. 2, no. 1, hal.34-38, Mar, 2014. 